\title{
Religiositas dan Stres Menghadapi Ujian Nasional pada Siswa Sekolah Menengah Umum
}

\author{
Belladina Aulina \\ H. Fuad Nashori \\ Fakultas Psikologi dan Ilmu Sosial Budaya, Universitas Islam Indonesia, Yogyakarta \\ Email : aulinabelladina@yahoo.com
}

\begin{abstract}
The purpose in the research is to understand the correlation between religiosity and stress ahead of national exam in high school students. The hypothesis of this research is that there is negative correlation between religiosity and the stress ahead of national exams in high school students. The higher the religiosity, the lower stress ahead of the national exam. The lower the religiosity, the higher stress ahead of the national exam. Subjects of this research were students of the $3^{\text {rd }}$ grade of high school. This research used the religiosity scale which is arranged by the researcher, based on the dimensions of religiosity according to Glock and Stark (Ancok \& Suroso, 2008) and the stress scale, based on the theory of Sarafino (1994). Method of this research was used to verify the negative correlation between religiosity and stress ahead a national exam in high school students. Product moment correlation of Pearson shows the value of $r=-0.176$ with $p=0.040$ ( $p<$ 0.05), which means that there is a significant negative correlation between religiosity and stress ahead of national exams in high school students, thus the hypothesis is accepted.
\end{abstract}

Key words: Religiosity, stress ahead of the national exam

Sumber daya manusia (SDM) yang berkualitas merupakan modal dasar untuk mewujudkan manusia seutuhnya dan masyarakat seluruhnya. Kualitas sumber daya manusia dipengaruhi oleh kualitas pendidikannya. Untuk meningkatkan kualitas pendidikan di Indonesia, pemerintah mempunyai program untuk para siswa sekolah yang disebut Ujian Nasional (UN). Ujian nasional ini adalah kegiatan penilaian hasil belajar siswa yang telah menyelesaikan jenjang pendidikan pada jalur sekolah yang diselenggarakan oleh pemerintah secara nasional dan dijadikan standar kelulusan siswa (www.depdiknas.go.id). Hasil ujian dapat dijadikan bukti konkret tentang kesanggupan pelajar untuk berpikir secara logis melalui proses yang memenuhi standar kompetensi yang ditentukan dan sesuai dengan prosedur akademik.

Standar kelulusan ujian nasional yang dari tahun ke tahun mengalami kenaikan ini seringkali membuat siswa menjadi stres. Pada tahun 2012 ini peserta UN yang dinyatakan lulus jika memenuhi standar kelulusan UN yaitu memiliki nilai rata-rata minimal 5,50 untuk seluruh mata pelajaran yang diujikan untuk SMP/SMA. Hal tersebut dinilai dapat meningkatkan beban kejiwaan siswa terutama beban psikologis (Sudaryanto,2008).

Syarat kelulusan yang cukup tinggi tersebut menimbulkan beban tersendiri bagi siswa apabila tidak lulus. Dampak yang dapat timbul akibat tidak lulus UN antara lain tertundanya siswa SMA untuk melanjutkan ke Perguruan Tinggi yang diinginkan, harus mengikuti program Kelompok Belajar (Kejar) Paket C. Stres yang berlebihan dalam menghadapi UN ini bisa mengacaukan emosi, mengganggu siklus tidur, menurunkan nafsu makan, dan menurunkan kebugaran tubuh. Hal tersebut bila terjadi dapat mengganggu konsentrasi dalam belajar, sakit secara fisik atau menimbulkan masalah dalam berinteraksi-sosial. Seperti yang terjadi di Bengkulu, beberapa siswa SMA tidak bisa mengikuti ujian nasional karena diduga mengalami gangguan jiwa atau mental (Antara News,2012). 
Fenomena stres menjelang ujian nasional pada siswa SMA juga terungkap dari hasil wawancara peneliti dengan beberapa siswa SMA Negeri 1 Banjarnegara. Siswa kelas XII cenderung mengalami stres menjelang UN. Seorang siswa mengaku ketika menjelang ujian nasional susah tidur, merasa tidak tenang, sering menangis, takut tidak bisa mengerjakan soal ujian,takut soalnya susah, takut tidak lulus, dan sulit berkonsentrasi belajar.

Hal di atas sejalan dengan yang ditulis oleh Kompas (Februari,2010) mengenai kesiapan mental siswa menjelang UN yang berisi:

"Surabaya- Menjelang dilaksakannya UN 2010, Dewan Pendidikan Jawa Timur mengimbau seluruh guru untuk meyiapkan mental siswanya. Ini perlu dilakukan karena banyaknya siswa yang cenderung mengalami gangguan psikologis atau stres menjelang UN. Ketua Dewan Pendidikan Jatim menjelaskan banyak fenomena yang muncul menjelang UN seperti siswa yang kerap menangis atau bahkan kesurupan. "Tahun ini dengan mempersiapkan mental siswa sejak awal dan mengawasi psikologis siswa,katanya".

Sarwono (2003) mengatakan stres adalah kondisi kejiwaan ketika jiwa itu mendapat beban. Perasaan stres yang dialami oleh siswa ketika menghadapi ujian merupakan respons (reaksi) yang berupa perasaan tidak nyaman atau tertekan terhadap tuntutan bahwa ujian nasional adalah penentu kelulusan (Jalaluddin,2008). Stres juga dapat disebabkan oleh gejalagejala fisik yang berlangsung terlalu lama, seperti dalam merespon tantangan dan perubahan dalam kehidupan sehari-hari. Stres menjadikan tubuh bekerja secara berlebihan yang dapat membuat perasaan cemas, takut, khawatir dan tegang. Perubahan sekecil apapun dapat membuat seseorang merasa tertekan atau merasa stres, bahkan perubahan yang baik sekalipun. Hal ini bukan hanya disebabkan oleh perubahan atau kejadian itu sendiri, tetapi juga reaksi seseorang terhadap perubahan yang terjadi.

Menurut Syahril (2007), ujian nasional merupakan momok yang membuat tingginya tingkat stres. Dari pernyataan tersebut dapat diketahui bahwa tingginya tingkat stres merupakan bagian dari tekanan fisik dan mental yang sangat luar biasa yang dialami secara merata oleh semua orang yang menempuh pendidikan. Keberhasilan siswa menghadapi ujian pada umumnya, dan Ujian Nasional (UN) pada khususnya, dipengaruhi oleh berbagai faktor. Salah satunya adalah kemampuan menjawab pertanyaan secara tepat dan benar, setidak-tidaknya guna mencapai Standar Kelulusan Minimal. Agar sampai pada kondisi tersebut, siswa perlu mempersiapkan diri dengan sungguhsungguh sehingga benar-benar merasa mampu untuk menghadapi dan mengikuti ujian tersebut dengan kemampuan sendiri dan dengan hasil yang sebaik-baiknya.

Dari kenyataan di atas dapat dilakukan beberapa strategi ketika stres itu muncul, seperti tidak membebani diri secara berlebihan, tidak mempermasalahkan halhal yang sepele, mendekatkan diri kepada Allah dengan menjalankan perintah agama, dan menjadi seorang yang berpikir positif (Jalaluddin,2008). Perasaan stres yang dialami seorang siswa dalam menghadapi ujian nasional (UN) ternyata lebih disebabkan oleh pikiran dan perasaan yang tidak menyenangkan dalam menghadapi stresor kehidupan, kecenderungan berpikir seseorang baik positif maupun negatif akan membawa pengaruh terhadap penyesuaian dan kehidupan psikisnya. Orang yang cenderung berpikir negatif, pesimis, dan irasional akan lebih mudah mengalami stres daripada mereka yang cenderung berpikir positif, rasional, dan optimis. Salah satu cara agar seseorang terhindar dari pikiran yang negatif maka seseorang harus memiliki religiositas yang tinggi (Hardjana, 1994).

Menghadapi permasalahan dalam kehidupan, manusia sadar bahwa ia tidak sendirian. Saat ini mulai terlihat bahwa manusia kembali kepada hal - hal yang bernuansa agama atau spiritual untuk membantu permasalahan kehidupan yang semakin komplek. Agama meningkatkan kesejahteraan pada banyak individu dengan agama yang kuat lebih memiliki kebahagiaan personal yang lebih besar, dan terkena dampak yang lebih kecil dari kejadian traumatik dibandingkan dengan orang - 
orang yang tidak mau terlibat dengan agama (Ellison, 1991;Taylor, 1995).

Glock dan Strak (Ancok \& Suroso, 2008) menyatakan bahwa agama adalah sistem simbol, sistem keyakinan, sistem nilai, dan sistem perilaku yang terlembagakan, yang semua terpusat persoalan - persoalan yang dihayati sebagai suatu yang paling maknawi (ultimate meaning). Agama merupakan salah satu faktor yang mempengaruhi coping seseorang dari segi keyakinan.

Religiositas merupakan tingkah laku manusia yang sepenuhnya dibentuk oleh kepercayaan terhadap alam gaib. Dalam hal ini religiositas lebih melihat aspek yang ada di dalam lubuk hati dan tidak dapat dipaksakan (Bustanuddin,2006). Religiositas bukan berarti penghayatan terhadap nilai-nilai agama semata namun juga mensyaratkan adanya pengamalan nilainilai tersebut.

Menurut Rahayu (1997), dalam keadaan sehat ataupun sakit seseorang harus memandang dirinya tidak hanya sebagai makhuk bio-psiko-sosial saja melainkan juga memandang sebagai makhluk bio-psikososio-spiritual. Jadi dapat disimpulkan bahwa spiritual sebagai bagian dari religiositas memegang peranan yang besar dalam menghadapi masalah, supaya stres tidak berlanjut.

Kesiapan dalam menghadapi Ujian Nasional mutlak diperlukan bagi peserta Ujian Nasional. Salah satu upaya agar mereka terhindar dari stres yang berlebihan adalah dengan mengoptimalkan religiositas mereka. Peran agama sangat dibutuhkan dalam mengatasi stres yang timbul saat akan menghadapi ujian nasional. Sebagaimana studi yang dilakukan terhadap 62 pasien psikiatri yang beragama Islam, yang mengalami gangguan stres. Sebagian pasien menerima pengobatan secara konvensional yaitu diberi obat anti depresi dan psikoterapi suportif. Sebagian lagi mendapatkan terapi yang sama akan tetapi ditambah dengan psikoreligius yaitu seperti berdoa, berzikir, dan mengkaji ataupun membaca Al Quran. Hasil yang diperoleh membuktikan bahwa pasien yang menerima tambahan terapi psikoreligius menunjukkan perbaikan yang pesat atau bermakna dari gejala-gejala stres dibandingkan dengan pasien yang hanya mendapatkan terapi konvensional (Azhar, dalam Hawari,2003).

Berbagai masalah di atas dapat dilihat adanya hubungan antara religiositas dan stres. Stres yang dialami oleh siswa kelas XII menjelang ujian nasional serta efek-efek yang mungkin timbul dari stres yang berlebihan dan disisi lain keterlibatan religiositas secara teoritis dapat menciptakan rasa aman dan tenang sehingga stres dapat dihindari, maka peneliti ingin membuktikan hubungan antara religiositas dengan stres menjelang ujian nasional pada siswa SMA. Hipotesis yang diajukan adalah ada hubungan negatif anatar religiositas dan stres menghadapi UN pada siswa SMU.

\section{METODE PENELITIAN}

\section{Subjek penelitian}

Subjek penelitian yang digunakan oleh peneliti adalah siswa SMA Negeri 1 Banjarnegara kelas XII jurusan IPA atau IPS beragama Islam yang berusia antara $16-18$ tahun berjenis kelamin laki - laki dan perempuan. Serta siswa yang memiliki nilai rapor rata-rata 7,00 pada semester 5 .

\section{Metode Pengumpulan Data}

\section{Religiositas}

Pengumpulan data religiositas dilakukan dengan menggunakan skala religiositas. Skala ini merupakan skala yang berisi sejumlah pernyataan untuk mengungkap keadaan respon yang sebenarnya dalam hal ini religiositas subjek. Skala ini dibuat sendiri oleh penulis dengan mengacu pada dimensi religiositas Islam menurut Ancok \& Suroso, (2008), yaitu dimensi keyakinan, dimensi praktik agama, dimensi pengamalan, dimensi pengetahuan, dimensi penghayatan.

Sebelum diujicobakan skala ini terdiri dari 60 aitem yang terdiri dari 2 Skala Religiositas. Pada Skala Religiositas 1 meliputi dimensi keyakinan, praktik agama, penghayatan, dan pengamalan yang di ajukan kepada subjek yang berjumlah keseluruhan aitem adalah 48 butir, terdiri dari 
24 aitem favourable dan 24 aitem unfavorable. Terdiri dari 4 kategori pilihan, pada aitem favorable skor yang diberikan yaitu Sangat Sesuai (SS) diberi skor 4, Sesuai (S) diberi skor 3, Tidak Sesuai (TS) diberi skor 2, Sangat Tidak Sesuai (STS) diberi skor 1. Sedangkan pada aitem unfavourable skor yang diberikan yaitu Sangat Sesuai (SS) diberi skor 1, Sesuai (S) diberi skor 2, Tidak Sesuai (TS) diberi skor 3, Sangat Tidak Sesuai (STS) diberi skor 4. Skor total yang diperoleh dari keseluruhan jumlah aitem pada skala ini menunjukan semakin tinggi skor semakin tinggi pula tingkat religiositas, sebaliknya semakin rendah skor menunjukan semakin rendah tingkat religiositas. Uji koefisien reliabilitas yang digunakan adalah cronbach alpha diperoleh nilai koefisien alpha 0,938 dan koefisien korelasi total antara 0,322 sampai 0,689 .

Selanjutnya Skala Religiositas 2 berisi mengenai pengetahuan agama yang berbentuk pilihan ganda dalam memberikan jawaban, subjek diberi empat alternatif jawaban, nilai jawaban yang diberikan adalah benar diberi nilai 1 dan salah diberi nilai 0 . Jumlah jawaban subjek yang benar menunjukkan tingkat pengetahuan beragama. Uji koefisien reliabilitas yang digunakan adalah cronbach alpha diperoleh koefisien alpha 0,906 dan koefisien korelasi aitem total bergerak dari 0,448 sampai 0,838 .

2. Stres

Pengumpulan data stres diungkap dengan menggunakan skala stres yang dibuat sendiri oleh peneliti berdasarkan teori yang dikemukakan oleh Sarafino (1994) yang meliputi reaksi biologis dan psikologis (gejala kognisi, gejala emosi, dan gejala tingkah laku). Berdasarkan aspek diatas jumlah keseluruhan aitem yang berhasil dibuat adalah 48 butir, terdiri dari 24 aitem favorable dan 24 aitem unfavorable. Bentuk aitem pada skala ini berupa pernyataan dengan empat alternatif jawaban, yaitu pada aitem favourable skor yang diberikan yaitu Sangat Sesuai (SS) diberi skor 4, Sesuai (S) diberi skor 3, Tidak Sesuai (TS) diberi skor 2, Sangat Tidak Sesuai (STS) diberi skor 1. Sedangkan pada aitem unfavourable skor yang diberikan yaitu Sangat Sesuai (SS) diberi skor 1, Sesuai (S) diberi skor 2, Tidak Sesuai (TS) diberi skor 3, Sangat Tidak Sesuai (STS) diberi skor 4. Uji koefisien reliabilitas yang digunakan adalah cronbach alpha memperoleh koefisien alpha sebesar 0,939 dan koefisien korelasi aitem total antara $0,318-0,760$.

\section{Metode Analisis Data}

Penelitian ini termasuk jenis penelitian korelasional, yaitu mencari hubungan antara religiositas dengan stres menjelang ujian nasional pada siswa SMA. Peneliti menggunakan analisis statistik untuk metode analisis data. Penelitian ini menggunakan uji korelasi Product Moment dari Pearson. Teknik Korelasi ini digunakan untuk mengetahui ada tidaknya hubungan antara religiositas dengan stres menjelang ujian nasional pada siswa SMA. Pengolahan data dilakukan peneliti dengan mengunakan program SPSS 16.0 for Windows.

\section{HASIL PENELITIAN}

\section{Uji Asumsi}

Uji asumsi dilakukan dengan uji normalitas dan linearitas. Uji normalitas dengan menggunakan teknik one-sample Kolmogorov-smirnov dari program SPSS 16.0 for Windows menunjukkan K-SZ sebesar 0,580 dengan nilai $\mathrm{p}=0,889(\mathrm{p}>$ $0,05)$ untuk stres. Nilai K-SZ sebesar 0,134 dengan nilai $\mathrm{p}=0,285(\mathrm{p}>0,05)$ untuk religiositas. Hasil uji normalitas ini menunjukkan bahwa religiositas dengan stres memiliki sebaran normal.

Hasil Uji Linieritas dengan menggunakan SPSS 16.0 for windows dengan teknik compare means menunjukkan $\mathrm{F}$ linierity $=5,787$ dan $\mathrm{p}=0,018$. Berdasarkan hasil analisis di atas dapat dikatakan bahwa hubungan antara variabel stres menjelang ujian nasional dengan religiositas adalah linier karena $p<0,05$.

\section{Uji Hipotesis}

Uji hipotesis dilakukan untuk mengetahui hubungan antara religiositas 
dengan stres menjelang ujian nasional. Uji hipotesis ini menggunakan analisis statistik Product Moment dari Pearson dengan menggunakan program SPSS 16.0 for Windows. Hasil analisis data menunjukkan korelasi antara variabel religiositas dan stres menjelang ujian nasional $\mathrm{r}=-0,176$ dengan $\mathrm{p}=0,040(\mathrm{p}<0,05)$. Hal ini berarti semakin tinggi religiositas seseorang maka semakin rendah stres dan sebaliknya. Dengan demikian ada hubungan negatif yang signifikan antara religiositas dengan stres menjelang ujian nasional pada siswa SMA. Dengan demikian hipotesis yang di ajukan diterima.

\section{PEMBAHASAN}

Hasil analisis data dengan teknik Product Moment Pearson menunjukkan bahwa ada korelasi negatif yang signifikan antara religiositas dan stres menjelang ujian nasional pada siswa SMA. Korelasi antara variabel religiositas dan stres menjelang ujian nasional ditunjukkan oleh nilai $\mathrm{r}=$ 0,176 dengan $p=0,040(p<0,05)$. Semakin tinggi religiositas seseorang maka semakin rendah stres dan sebaliknya.

Hasil penelitian ini sesuai dengan pendapat Thouless (1992) yang mengungkapkan bahwa stres dipengaruhi oleh religiositas. Religiositas ini menyangkut hubungan kedekatan individu dengan Sang Maha Pencipta. Kedekatan tersebut dapat membuat seseorang menjadi tenang sehingga terhindar dari rasa cemas dan stres. Sedangkan orang yang tidak merasa tenang, aman serta tentram dalam hatinya adalah orang yang sakit rohani atau mentalnya. Seperti yang diungkap oleh Jalaluddin (2005), bahwa orang yang mengalami sakit rohani atau mentalnya akan terjadi pertentangan atau konflik dalam batin. Pertentangan tersebut bisa menimbulkan stres yang muncul karena adanya keinginan dengan kenyataan yang tidak sesuai. Oleh karena itu diharapkan para siswa SMA khususnya kelas XII untuk memiliki meningkatkan religiositasnya agar dapat mengurangi stres yang dialami.

Menurut Sarafino (1994), stres disebabkan oleh transaksi antara individu dengan lingkungan yang menimbulkan persepsi jarak antara tuntunan-tuntunan yang berasal dari situasi dengan sumber-sumber daya biologis, psikologis, dan sosial seseorang. Kondisi ini bisa menjadikan seseorang tertekan secara psikis yang disebabkan pengalaman fisik maupun psikis yang tidak menyenangkan.. Fenomena stres yang dirasakan oleh individu merupakan satu fenomena kognitif yang terfokus hanya pada ketakutan dengan hasil yang negatif di masa lampau atau ketidakjelasan hasil di masa depan.

Orang yang cenderung berpikir negatif, pesimis dan irasional akan lebih mudah mengalami stres daripada mereka yang cenderung berpikir positif, rasional dan optimis. Agar terhindar dari pikiran yang negatif, maka seseorang harus memiliki religiositas yang tinggi (Hardjana, 1994). Cara pandang positif dan keyakinan terhadap kehidupan yang terbangun dengan religiusitas dapat memunculkan daya tahan dan kemampuan menghadapi permasalahan yang sekiranya dapat menimbulkan stres.

Penelitian tersebut juga sejalan dengan pernyataan bahwa perasaan stres yang dialami seseorang ternyata lebih disebabkan oleh pikiran dan perasaan yang tidak menyenangkan dalam menghadapi sumber stres kehidupan, kecenderungan berpikir seseorang baik positif maupun negatif akan membawa pengaruh terhadap penyesuaian dan kehidupan psikisnya. Menurut Bukhori (2006), pelaksanaan ibadah yang diajarkan dalam Islam akan mampu memberikan pengaruh positif jika dilakukan sesuai dengan pedoman yang disampaikan oleh Allah.

Religiositas tersusun atas beberapa dimensi, antara lain dimensi keyakinan, ibadah, penghayatan, pengamalan dan pengetahuan agama (Ancok \& Suroso, 2008). Dimensi keyakinan menekankan pada keyakinan individu terhadap kekuasaan, kebenaran dan kemutlakan Allah atas apa yang terjadi dan akan terjadi dalam kehidupannya, keyakinan dan keimanan terhadap kekuasaan Sang Pencipta 
menekankan individu untuk tidak mengkhawatirkan keberadaan dirinya karena Allah senantiasa memberikan jalan yang terbaik bagi umatnya. Dimensi Ibadah merupakan kepatuhan individu dalam melaksanakan tugas-tugas agama, kepatuhan menjalankan tugas agama akan memunculkan perasaan dekat dengan Allah, sebuah kedekatan dengan Sang Pencipta pada akhirnya akan memunculkan kepasrahan dan pemakluman atas kuasanya sehingga individu dapat merasa lebih tenang dan yakin dengan kehidupan yang dijalaninya. Kedekatan dengan Allah tercakup dalam dimensi Ihsan, misalnya merasa doa-doanya didengar oleh Allah, merasa senantiasa dalam lindungan Allah dan perasaan syukur atas nikmat yang dikaruniakan Allah terhadap kehidupan (Ancok \& Suroso, 2008).

Dimensi ibadah dan penghayatan menekankan seorang umat untuk menerima dan meyakini kehidupan yang dijalaninya dengan sepenuh hati, berdasarkan pemahaman bahwa Allah tidak akan mengabaikan umatnya, namun senantiasa menuntun dan membimbing ke jalan yang benar. Subjektivitas yang dirasakan tersebut dapat dikategorikan ke dalam skema kognitif yang mengarahkan perilaku individu dan membentuk situasi emosi positif dalam diri individu. Seperti dijelaskan oleh Berkowitz (1995) bahwa pemahaman kognitif seseorang dapat menstimulasi munculnya afeksi atau situasi emosi yang sejalan dengan kerangka kognitif yang terbentuk. Hal ini dapat dianalogikan seseorang yang meyakini bahwa Allah senantiasa melindungi, menuntun dan memberikan jalan, maka ia cenderung merasa positif dan yakin ketika menghadapi permasalahan sekaligus dapat menjauhkan atau mengurangi stres yang dialami seseorang.

Penelitian ini menunjukkan bahwa religiositas dapat mempengaruhi tingkat stres yang di alami seseorang. Dapat dilihat dari faktor yang mempengaruhi religiositas seseorang, yaitu salah satunya pengaruh pendidikan dan berbagai tekanan sosial (Thouless, 1992). Dalam hal ini para siswa
SMA yang mengalami stres akibat tekanan menghadapi ujian nasional dapat juga mempengaruhi religiositasnya. Jika seorang siswa memiliki religiositas tinggi cenderung terkendali karena pada dasarnya agama mengajarkan pengendalian emosi, akan secara otomatis mengatur sikap dan perilaku dalam kehidupan sehari - hari (Subandi, 1988). Sehingga individu terhindar dari stres yang dapat mengakibatkan perasaan tidak bahagia di dalam dirinya dan menjadi tertekan. Stres menjelang UN merupakan situasi dan perasaan yang dialami ketika seseorang merasakan adanya tuntutan yang melebihi daya kemampuan pribadi dan sosial. Stres ini muncul karena adanya rasa takut menghadapi UN yang hasilnya tidak sesuai harapan yang diinginkan siswa.

Jika dilihat antara kenyataan di lapangan dengan hasil penelitian keadaannya tidaklah sama atau terjadi perbedaan. Hal ini wajar saja terjadi karena ada beberapa faktor yang di luar kendali penulis dan tidak dapat dikontrol sehingga mempengaruhi hasil penelitian. Adapun beberapa sebab yang menjadikan mengapa penelitian ini kurang dapat mengungkap fakta sebenarnya yang terjadi dilapangan: (1) saat melakukan penelitian, subjek sering melakukan perbincangan dengan teman sebelah, (2) usia subjek yang tergolong masih muda sehingga pemikiran yang terkadang tidak stabil, (3) pernyataan-pernyataan yang dibuat penulis dalam skala yang diberikan kurang mengungkap hal yang terjadi, (4) adanya bias dari subjek sehingga tidak dapat mengungkap fakta yang sebenarnya, (5) pengisian kuosioner oleh siswa kurang bisa dilakukan dengan penuh konsentrasi karena situasi ruang yang kelas yang cukup ramai (tidak kondusif).

\section{PENUTUP}

Berdasarkan hasil penelitian, dapat disimpulkan bahwa ada hubungan negatif yang signifikan antara religiositas dan stres menjelang ujian nasional pada siswa SMA. Hal ini berarti semakin tinggi religiositas seseorang, semakin rendah stres menjelang ujian nasional. Begitu juga sebaliknya 
semakin rendah religiositas, maka semakin tinggi stres yang dialami siswa menjelang ujian nasional. Dengan demikian, hipotesis yang diajukan sebelumnya dapat diterima.

\section{DAFTAR PUSTAKA}

Ancok, D, \& Suroso, F. N. (2008). Psikologi Islami. Yogyakarta: Pustaka Pelajar.

Anshari, E. S. (1989). Pendidikan Agama Islam di Perguruan Tinggi. Jakarta: Rajawali.

Atkinson, R. L. \& Atkinson, R.C. (2000). Introduction to Psychology (13th Edition). Harcourt College Publisher.

Azwar, S. (1997). Reliabilitas dan Validitas. Yogyakarta: Penerbit Pustaka Pelajar.

Baldwin, R.D. (2002). Stress and Illnes in Adolescence: Issue of Race and Gender. Diunduh pada tanggal $10 \mathrm{Mei}$ 2011 dari http://www.fidarticles.com/

Berkowitz, L. (1995). Agresi, Sebab dan Akibatnya. Jakarta: PT Pustaka Binaman Pratindo.

Bukhori, B. (2006). Kesehatan Mental Mahasiswa Ditinjau dari Religiusitas dan Kebermaknaan Hidup. Jurnal Psikologika, 11(22), 93-105.

Chaplin, J. P. (2001). Kamus Lengkap Psikologi. Jakarta: PT Raja Grafindo Persada.

Daradjat, Z. (1972). Ilmu Djiwa Agama. Jakarta: Bulan Bintang.

Daradjat, Z. (1988). Dampak Ibu di Rumah Bagi Anak. Kompas hal I : 9. Jakarta: Pusat Informasi Wanita dalam Pembangunan dengan Yayasan Ilmuilmu Sosial.

Depdiknas. (2011). Peraturan Menteri Pendidikan Nasional Nomor 75 Tahun 2

$\begin{array}{lll}0 & 1 & 1\end{array}$.

www.depdiknas.go.id/produk hukum/ permen/permen_75 20011.pdf

Durand, W \& Bartow, D. (2007). Intisari Psikologi Abnormal Buku Kedua Edisi Keempat. Yogyakarta: Pustaka Pelajar.

Hardjana, A. M. (1994). Stres Tanpa Distres.Seni Mengolah Stres. Jakarta: Kanisius.

Jalaluddin. (2005). Psikologi Agama (edisi revisi). Jakarta: PT. Raja Grafindo Persada.

Lazarus, R. S., Folkman, S. (1984). Stress, Appraisal and Coping. New york: Springer publishing company.

Mangunwijaya, Y.B. (1982). Sastra dan Religiusitas. Jakarta: Sinar Harapan.

Nasir, M. (1983). Metode Penelitian. Jakarta: Penerbit Ghalia

Nashori, F. (1997). Manusia Sebagai Homo Religious. Jurnal Pemikiran dan Penelitian Psikologika 3, 3-5.

Sarafino, E.P. (1994). Health Psychology (2nd ed). New York : John Wiley and Sons.

Setyaningsih, R. (2007). Mengatasi Kecemasan Menghadapi Ujian Nasional. Diunduh pada tanggal 21 April 2011 dari http://bempsychologyunissula.blog.friendster.com/

Sudaryanto. (2008). UN \& Dualisme Pembelajaran. Diunduh pada 30 Juni 2011 dari http:// www.pelita.or.id.html

Tanumidjojo,Y., Basoeki,S.L., Yudiarso,A. (2004). Stres dan Perilaku Koping Pada Remaja Penyandang Diabetes Mellitus Tipe I. Anima, Indonesian Psychological Journal.19(4), 399-406

Thouless, R.H. (1992). Pengantar Psikologi Agama. Jakarta Rajawali. 
.(2002). Mengatasi Stres Pada Remaja.Diunduh pada tanggal 9 April 2011 dari : http://www.ramuracik.com/

.(2002). Mengenal Stres pada Anak Remaja. Diunduh pada tanggal 10 A p r i 120011 d a r i : http://www.sekolahindonesia.com/
.(2010). Dewan Pendidikan: Jelang UN Persiapkan Mental Siswa. Diunduh pada tanggal 18 April 2012 dari : http://dikporapapua.org/

.(2012). Batal Ikut UN Karena Stres. Diunduh pada tanggal 18 April 2012 dari : http://m.antaranews.com/ 